\title{
PENGEMBANGAN PERANGKAT PEMBELAJARAN YANG MENGINTEGRASIKAN KIT LISTRIK DAN PHET MELALUI MODEL KOOPERATIF STAD PADA SISWA KELAS V SD
}

\author{
M. Farid Nusawiguna ${ }^{1}$, Mohammad Nur ${ }^{2}$, Wahono Widodo ${ }^{3}$ \\ Pendidikan Dasar, Pascasarjana Universitas Negeri Surabaya \\ email: madiun_gun@yahoo.com
}

\begin{abstract}
Abstrak
Penelitian ini dilatarbelakangi oleh fakta di lapangan bahwa kemampuan siswa dalam menguasai dan memanfaatkan materi IPA masih rendah. Sebagian besar siswa kelas V belum memahami pelajaran dengan baik. Hal ini disebabkan oleh guru belum memanfaatkan media yang disediakan sekolah, kegiatan pembelajaran didominasi guru, dan siswa bersikap pasif. Penelitian ini bertujuan untuk mengembangkan perangkat pembelajaran yang mengintegrasikan media KIT listrik dan PhET melalui model kooperatif tipe STAD. Pengembangan perangkat pembelajaran mengacu pada model 4D dari Thiagarajan (1974). Desain uji coba yang digunakan adalah one group pretes posttest design. Subjek uji coba perangkat pembelajaran ini adalah siswa kelas V SDN Menur Pumpungan V/510 Surabaya. Teknik pengumpulan data yang digunakan adalah pengisian daftar checklist, observasi, pemberian tes. Instrumen yang digunakan dalam penelitian ini adalah lembar checklist, lembar pengamatan, dan lembar tes. Data yang diperoleh dianalisis menggunakan pendekatan deskriptif kuantitatif dan kualitatif. Hasil penelitian menunjukkan bahwa perangkat yang dikembangkan memiliki skor ratarata validitas sebesar 3,89 sehingga dapat dikategorikan valid dan layak digunakan dalam kegiatan pembelajaran. Kepraktisan perangkat RPP mencapai 3,56 sehingga termasuk dalam kategori sangat baik. Aktivitas siswa yang dominan antara lain melakukan percobaan $(23 \%)$, menulis $(21 \%)$, menggambar $(10 \%)$, dan berdiskusi $(9,6 \%)$. Ketuntasan hasil belajar siswa untuk indikator aspek sikap mencapai 3,48 dengan kategori baik. Ketuntasan hasil belajar siswa untuk indikator aspek pengetahuan IPA mencapai 3,35 dengan kategori baik. Ketuntasan hasil belajar siswa untuk indikator aspek keterampilan IPA mencapai 3,34 dengan kategori baik. Respon siswa terhadap pelaksanaan kegiatan pembelajaran adalah positif, seluruh siswa menyatakan senang mengikuti kegiatan pembelajaran
\end{abstract}

Kata Kunci: Pengembangan, Perangkat Pembelajaran, Media KIT, PhET, STAD.

\begin{abstract}
This study is based on the fact that student's ability in mastering and using their knowledge in science is low. The most students of fifth graders can't understand the lesson well. It caused by the teacher didn't use learning media yet, teacher also dominates the learning, and the students are passive. This study aim's to develop a learning devices were integrated Electrical KIT and PhET through STAD cooperative learning. Development of this learning devices refers to the the 4D model from Thiagarajan (1974). The study design is one group pretes posttest design. The subject of this experiment are fifth graders of SDN Menur Pumpungan V/510 Surabaya. Data collection technique were used are fill checklist, observation, and do a tes. Instrument were used in this research are checklist sheet, observation sheet, and paper test. The analysis of data were collected use descriptive qualitative and quantitave approach. The study result shows that learning devices which is developed gets validity score 3,89 so it can categorize valid and suitable to use in learning. The learning devices practicality is 3,56 so it can categorize very good. The students activities are dominated by experiment $(23 \%)$, writing $(21 \%)$, drawing $(10 \%)$ and discussion $(9,4 \%)$.The students accomplishment of attitudes indicator gets 3,52 , it categorizes very good. The students accomplishment of knowledge indicator gets 3,35, it categorizes good. The students accomplishment of skill indicator gets 3,34, it categorizes good. The students response in learning is positive, all students clarify that enjoy the learning.
\end{abstract}

Keywords: Development, Learning devices, KIT Media, PhET, STAD

\section{PENDAHULUAN}

Ilmu pengetahuan alam (IPA) merupakan salah satu mata pelajaran yang diajarkan di satuan pendidikan sekolah dasar. Dalam mempelajari materi IPA, siswa tidak hanya dituntut untuk mampu menghafal kumpulan materi, konsep, atau fakta-fakta yang terjadi saja, tetapi juga dituntut untuk mampu mengembangkan segenap potensi diri dan lingkungannya (Depdiknas, 2008:147).

Ada tiga komponen penting dalam pembelajaran IPA, yaitu 1) sikap ilmiah, 2) proses ilmiah, dan 3) produk ilmiah (Khaeruddin dan Sujiono, 2005:13). Sikap ilmiah merupakan sikap 
seseorang dalam mempelajari materi IPA berupa tanggung jawab, keinginan untuk mengetahui lebih banyak tentang materi IPA, jujur, terbuka, objektif, kreatif, teliti, dan percaya diri. Proses ilmiah dalam kegiatan pembelajaran IPA diwujudkan melalui pengembangan keterampilan proses bagi siswa. Pengajaran teori, fakta maupun konsep IPA masih belum memenuhi komponen penting dalam pembelajaran IPA karena baru mengajarkan tentang produk ilmiah saja. Sikap ilmiah berguna bagi seseorang agar mampu memahami fenomena atau pengetahuan IPA dengan tepat. Proses ilmiah akan mendukung pemahaman siswa terhadap produkproduk ilmiah seperti teori atau fakta.

Dalam Lampiran Permendikbud Nomor 81A Tahun 2013 dijelaskan bahwa untuk mencapai kualitas pembelajaran yang telah ditetapkan, pembelajaran perlu menggunakan beberapa prinsip, yaitu 1) mengakomodasi interaksi belajar yang aktif antara guru dan siswa, (2) mengembangkan kreativitas peserta didik, (3) menciptakan kondisi menyenangkan dan menantang, (4) bermuatan nilai, etika, estetika, logika, dan kinestetika, dan (5) menyediakan pengalaman belajar yang beragam melalui penerapan berbagai strategi dan metode pembelajaran yang menyenangkan, kontekstual, efektif, efisien, dan bermakna.

Berdasarkan hasil pengamatan terhadap pelaksanaan pembelajaran, diketahui bahwa kegiatan pembelajaran yang dilakukan masih berpusat pada guru. Siswa hanya mendengarkan penjelasan guru kemudian mengerjakan soal latihan yang ada di buku. Kegiatan pembelajaran ini berdampak pada kurangnya aktivitas siswa untuk belajar secara mandiri maupun sosial. Padahal tujuan dari proses pendidikan bukan hanya berusaha meningkatkan pengetahuan siswa saja, melainkan juga meningkatkan dimensi sikap dan keterampilan siswa. Frekuensi kegiatan percobaan dalam pembelajaran IPA jarang dilakukan di kelas. Padahal kegiatan percobaan dapat melatih siswa untuk belajar mengenai proses ilmiah dan sikap ilmiah bukan hanya berpusat pada produk ilmiah saja. Hal ini berdampak pada ketidaktercapaian target yang telah ditetapkan. Nilai ulangan harian sebagian besar siswa kelas $\mathrm{V}$ belum mencapai kriteria ketuntasan minimal (KKM) yang ditetapkan. Hasil belajar siswa pada ulangan harian I, diketahui $68 \%$ siswa belum memenuhi KKM, pada ulangan harian II terdapat $59 \%$ siswa tidak memenuhi KKM, pada UTS I terdapat $65 \%$ siswa belum memenuhi KKM.
Berdasarkan uraian tersebut, diketahui bahwa terdapat permasalahan pembelajaran IPA. Pembelajaran yang didominasi oleh guru mengakibatkan siswa cenderung untuk pasif dan hanya mendengarkan materi yang dijelaskan guru. Keadaan ini mengakibatkan program pengembangan aspek pengetahuan (kognitif), sikap, serta keterampilan belum optimal. Padahal dalam pembelajaran IPA dapat dilakukan berbagai kegiatan yang menarik serta mewadahi pengembangan dimensi pengetahuan, sikap, maupun keterampilan siswa. Kegiatan percobaan untuk mengembangkan kemampuan siswa dalam menggali berbagai informasi serta fakta di alam yang mendukung pemahaman siswa terhadap materi IPA juga belum dilaksanakan dengan optimal. Informasi yang disampaikan guru menjadi sumber pengetahuan utama bagi siswa. Keterampilan berpikir kritis siswa untuk tidak sertamerta menerima informasi yang diterima juga belum berkembang.

Berdasarkan uraian di atas, perlu dikembangkan perangkat pembelajaran inovatif untuk meningkatkan kualitas pembelajaran dan hasil belajar siswa yang sesuai dengan pedoman pengembangan perangkat pembelajaran Kurikulum 2013. Perangkat pembelajaran tersebut terdiri atas silabus, Rencana Pelaksanaan Pembelajaran, Lembar Kegiatan Siswa, Bahan Ajar Siswa, dan Lembar Penilaian. Perangkat pembelajaran ini merupakan sarana bagi guru dalam melaksanakan pembelajaran dengan menggunakan media PhET dan KIT IPA dalam pembelajaran kooperatif tipe STAD.

Rumusan masalah umum dalam penelitian ini adalah bagaimanakah mengembangkan dan mendeskripsikan validitas, kepraktisan, dan efektivitas perangkat pembelajaran untuk mengimplementasikan media PhET dan KIT listrik melalui pembelajaran kooperatif tipe STAD pada siswa kelas V SDN Menur Pumpungan V/510 Surabaya?

Masalah umum tersebut diuraikan menjadi masalah-masalah khusus, yaitu bagaimanakah validitas perangkat pembelajaran yang dikembangkan? Bagaimanakah kepraktisan perangkat tersebut? Bagaimanakah efektivitas perangkat pembelajaran ditinjau dari aktivitas siswa, hasil belajar siswa, dan respon siswa, serta kendala-kendala yang terjadi dalam penerapan kegiatan pembelajaran yang mengimplementasikan 
media PhET dan KIT listrik dalam pembelajaran kooperatif tipe STAD?

Tujuan penelitian ini adalah mengembangkan perangkat pembelajaran untuk mengimplementasikan media PhET dan KIT listrik dalam pembelajaran kooperatif tipe STAD pada siswa kelas V SDN Menur Pumpungan V/510 Surabaya dan mendeskripsikan validitas, kepraktisan, dan efektivitas perangkat tersebut.

KIT listrik merupakan seperangkat alat yang dapat digunakan untun memodel suatu rangkaian listrik. Sudjana dan Rivai (2005:156) mengemukakan bahwa model adalah tiruan tiga dimensional dari beberapa objek untuk dibawa ke dalam kelas dan dipelajari siswa dalam wujud aslinya. KIT dapat digunakan sebagai media belajar siswa melalui aktivitas percobaan. Kegiatan percobaan atau eksperimen memiliki peran penting dalam menghubungkan suatu konsep terhadap fakta yang terjadi berdasarkan hasil pengamatan siswa. Media KIT memungkinkan siswa untuk memeroleh pengalaman belajar secara langsung. Pengalaman belajar yang diperoleh siswa secara langsung menggunakan benda-benda konkret memiliki pengaruh yang besar terhadap pencapaian tujuan belajar. Sidharta dan Winduono (dalam Saidah, 2013:26) menyatakan bahwa ada banyak manfaat yang diperoleh dengan menggunakan alat IPA sederhana, yaitu 1) siswa menjadi lebih mudah dalam memahami konsep yang dipelajari dengan bantuan alat; 2) siswa dapat menerapkan pengetahuan yang dimiliki dan keterampilan IPA; 3) ada peningkatan keterampilan siswa dan membuat siswa menjadi lebih aktif belajar; 4) adanya peningkatan daya kreativitas siswa, dan 5) biaya pengadaan relatif lebih murah dan waktu pengadaan dapat diatur sesuai dengan kebutuhan.

PhET merupakan salah satu software komputer yang berupa simulasi interaktif berbasis riset yang dikembangkan oleh Universitas Colorado. Pengembangan PhET dilakukan dengan menggabungkan hasil penelitian yang sudah ada kemudian dibuat animasinya sehingga memungkinkan para siswa untuk menghubungkan fenomena kehidupan nyata dan ilmu yang mendasarinya. Simulasi-simulasi dari PhET dapat dipergunakan secara online maupun offline. Media PhET dapat membantu siswa dalam membentuk pemahaman konseptual terhadap materi ilmu pengetahuan, khususnya menunjukkan aspek yang tidak dapat diamati secara langsung oleh indera manusia, misalnya pergerakan elektron atau arus listrik dalam suatu rangkaian listrik. Media PhET juga dapat digunakan untuk mengatasi keterbatasan penggunaan peralatan yang terdapat di laboratorium nyata. PhET sebagai salah satu bentuk aktivitas pemanfaatan laboratorium virtual menunjukkan hasil yang positif terhadap respon maupun peningkatan prestasi siswa. keuntungan lain dari penggunaan media PhET adalah untuk mengatasi keterbatasan yang dialami saat melakukan aktivitas menggunakan peralatan dalam laboratorium nyata, seperti menghindarkan siswa dari bahaya kebakaran atau tersengat arus listrik saat melakukan percobaan.

Students Teams Achievement Division (STAD) merupakan salah satu pembelajaran kooperatif yang dikembangkan dan diteliti di Universitas John Hopkins. Slavin (dalam Sharan, 2009:4) mengemukakan bahwa ada tiga konsep penting dalam pembelajaran yang diterapkan dalam pembelajaran kelompok siswa, yaitu: a) adanya penghargaan kelompok, b) melatih siswa untuk memiliki tanggung jawab secara individu; dan c) adanya kesempatan yang sama bagi tiap kelompok untuk berhasil. Slavin (2005:151) mengemukakan bahwa ada beberapa tahapan dalam pembelajaran kooperatif tipe STAD, yaitu a) penyampaian tujuan pembelajaran dan materi pelajaran; b) siswa bekerja dan belajar dalam tim masing-masing; c) evaluasi; dan d) rekognisi tim (pemberian penghargaan).

\section{METODE}

Jenis penelitian ini adalah penelitian pengembangan, yaitu mengembangkan perangkat pembelajaran yang mengintegrasikan media KIT listrik dan PhET dalam pembelajaran kooperatif tipe STAD pada materi rangkaian listrik. Perangkat yang dikembangkan adalah silabus, Rencana Pelaksanaan Pembelajaran (RPP), Bahan Ajar Siswa (BAS), Lembar Kerja Siswa (LKS), dan Lembar Penilaian (LP).

Subjek penelitian ini adalah perangkat pembelajaran yang terdiri atas 1) silabus, 2) Rencana Pelaksanaan Pembelajaran, 3) Bahan Ajar Siswa, 4) Lembar Kegiatan Siswa, dan 5) Lembar Penilaian. Subjek uji coba perangkat pembelajaran yang dikembangkan ini adalah siswa kelas V SDN Menur Pumpungan V/510 Surabaya tahun pelajaran 2014-2015.

Rancangan pengembangan perangkat penelitian ini mengadaptasi pengembangan perangkat model 4D (four $D$ model) yang dikemukakan oleh Thiagarajan (1974). 
Pengembangan perangkat model 4D terdiri atas empat tahap, yaitu 1) pendefinisian (define), 2) perancangan (design), 3) pengembangan (develop), dan 4) penyebaran (disseminate). Berkaitan dengan keterbatasan peneliti, hasil penelitian ini tidak disebarkan pada sekolah lain sehingga tahapan yang dilaksanakan hanya sampai pada pengembangan (develop).

Rancangan penelitian yang digunakan adalah one group pretest-posttest design dengan ilustrasi sebagai berikut.

\section{$01 \times 02$}

Keterangan:

$\mathrm{O}_{1} \quad$ : pretes (tes awal untuk mengetahui kemampuan siswa sebelum diberikan perlakuan)

$\mathrm{X}$ : perlakuan, yaitu pembelajaran menggunakan model kooperatif Tipe STAD dengan memanfaatkan media KIT Listrik dan PhET

$\mathrm{O}_{2} \quad$ : posttest (tes akhir untuk mengetahui kemampuan siswa setelah diberikan perlakuan)

Teknik pengumpulan data yang dilakukan adalah pengisian lembar validasi, teknik observasi, teknik tes, penilaian diri, dan pengisian angket. Instrumen yang digunakan adalah lembar validasi perangkat pembelajaran, lembar pengamatan kepraktisan perangkat RPP, lembar pengamatan aktivitas siswa, lembar penilaian (tes hasil belajar), angket respon siswa, dan lembar pengamatan kendala-kendala dalam pelaksanaan kegiatan pembelajaran. Teknik analisis data yang digunakan dalam penelitian ini adalah deskriptif kualitatif dan kuantitatif.

\section{HASIL DAN PEMBAHASAN}

Perangkat pembelajaran yang dikembangkan peneliti meliputi: silabus, RPP, LKS, Lembar Penilaian, dan Bahan Ajar Siswa divalidasi oleh 2 pakar (dosen) dan 1 praktisi pendidikan dari jenjang sekolah dasar. Hasil penilaian validator terhadap perangkat pembelajaran yang dikembangkan peneliti dapat dilihat pada Tabel 1 berikut.

Tabel 1. Penilaian Perangkat Pembelajaran

\begin{tabular}{llll} 
No & $\begin{array}{l}\text { Komponen yang } \\
\text { divalidasi }\end{array}$ & $\begin{array}{l}\text { Nilai rata- } \\
\text { rata }\end{array}$ & kategori \\
\hline 1. & RPP & 3,98 & Sangat baik \\
2. & Bahan Ajar & 3,82 & Sangat baik \\
& Siswa & & \\
3. & Lembar Kerja & 3,88 & Sangat baik \\
\hline
\end{tabular}

\begin{tabular}{llcl}
\hline & Siswa & 3,87 & Sangat baik \\
4. & $\begin{array}{l}\text { Lembar } \\
\text { Penilaian }\end{array}$ & \multirow{2}{*}{3,85} & Sangat baik \\
5. & $\begin{array}{l}\text { Media } \\
\text { Pembelajaran }\end{array}$ & & \\
\hline
\end{tabular}

Instrumen RPP yang digunakan dalam penelitian ini dikategorikan sangat baik dengan alasan: a) Instrumen RPP yang dibuat sudah berorientasi pada model pembelajaran kooperatif tipe STAD dan pendekatan ilmiah; b) RPP disesuaikan dengan pedoman pengembangan RPP pada Kurikulum 2013; c) nilai rata-rata dari ketiga validator terhadap komponen RPP adalah 3,98 dan rata-rata nilai koefisien reliabilitas sebesar $96 \%$ sehingga instrumen RPP ini tergolong reliabel. Menurut Borich (1994) suatu instrumen dinyatakan reliabel apabila nilai percentage agreement minimal mencapai $75 \%$.

Bahan ajar siswa yang dikembangkan sudah dikategorikan baik dan layak digunakan. Hal ini didasarkan pada penilaian validator yang menunjukkan nilai 3,82. Penyajian BAS disesesuaikan dengan teori mengenai tahapan perkembangan anak dari Piaget serta teori Edgar Dale mengenai proses pemerolehan informasi, yaitu dengan menyertakan gambar-gambar yang memperjelas uraian materi. Dalam teori Edgar Dale (Dalam Munadi, 2012:19) dijelaskan bahwa penggunaan gambar berkontribusi sebesar $20 \%$ terhadap kemampuan siswa dalam mengingat suatu informasi. Piaget (dalam Nasution, 2010:8) menjelaskan bahwa siswa kelas V SD berada pada tahap operasional konkret. Siswa memerlukan alat bantu untuk membuat materi yang dipelajari seolaholah menjadi nyata atau konkret. Berkaitan dengan hal tersebut, dalam BAS ini dilengkapi gambargambar yang menunjukkan rangkaian listrik maupun penggunaannya dalam kehidupan seharihari. Hal ini berdampak positif terhadap respon siswa yang menyatakan bahwa ilustrasi dan gambar yang digunakan dalam modul memudahkan siswa dalam memahami materi pelajaran.

Dalam setiap pembelajaran siswa dilatih untuk belajar secara langsung menggunakan benda konkret maupun secara visual dengan panduan yang tercantum dalam LKS. LKS yang dikembangkan dalam penelitian ini digolongkan dalam 2 jenis, yaitu panduan bagi siswa dalam melakukan kegiatan eksperimen memakai media konkret berupa KIT listrik dan media PhET.

Instrumen Lembar Penilaian yang digunakan untuk mengetahui hasil belajar siswa dalam penelitian ini terbagi dalam tiga aspek, yaitu sikap, 
pengetahuan, dan keterampilan. Instrumen lembar penilaian disusun dengan berpedoman pada Permendikbud Nomor 104 Tahun 2014. Penilaian yang dikembangkan menganut pendekatan penilaian acuan kriteria (PAK), yaitu semua kompetensi perlu dinilai dengan menggunakan acuan kriteria berdasarkan pada indikator hasil belajar. Berdasarkan Tabel 1 diketahui bahwa Instrumen Lembar Penilaian yang dinilai oleh tiga validator dikategorikan sangat baik dengan alasan skor rata-rata dari tiga validator adalah 3,87 dengan rata-rata koefisien reliabilitas mencapai $95 \%$. Instrumen yang digunakan untuk mengukur sikap siswa adalah instrumen pengamatan sikap siswa dan penilaian diri. Instrumen yang digunakan untuk mengukur pengetahuan siswa adalah instrumen lembar penilaian yang terdiri atas soal pilihan ganda dan soal uraian. Instrumen yang digunakan untuk mengukur keterampilan siswa adalah instrumen lembar pengamatan kinerja maupun penilaian produk siswa.

Kepraktisan Perangkat Pembelajaran

Rencana pelaksanaan pembelajaran digunakan sebagai pedoman bagi guru dalam melaksanakan serangkaian kegiatan pembelajaran. Rencana pelaksanaan pembelajaran yang digunakan terdiri atas 4 RPP. Pelaksanaan pembelajaran diamati oleh dua pengamat menggunakan Instrumen lembar pengamatan kepraktisan RPP. Hasil pengamatan tersebut ditunjukkan dalam Tabel 2 di bawah ini.

Tabel 2. Hasil pengamatan Kepraktisan RPP

\begin{tabular}{lllllll}
\hline & \multicolumn{5}{c}{ Kegiatan } & \multicolumn{3}{c}{ RPP ke- } & Rata- \\
No & Pembelajaran & $\mathbf{1}$ & $\mathbf{2}$ & $\mathbf{3}$ & $\mathbf{4}$ & rata \\
\hline 1 & Pendahuluan & 3,3 & 3,4 & 3,7 & 3,7 & 3,53 \\
2 & Kegiatan inti & 3,55 & 3,6 & 3,74 & 3,67 & 3,64 \\
3 & Penutup & 3,75 & 3,5 & 3,75 & 4 & 3,75 \\
4 & Pengelolaan & 3,5 & 3,5 & 3 & 3 & 3,25 \\
& waktu & & & & & \\
5 & Suasana kelas & 3,5 & 3,5 & 3,5 & 4 & 3,63 \\
Rata-rata & 3,52 & 3,5 & 3,54 & 3,67 & 3,56 \\
Reliabilitas & $98 \%$ & $96 \%$ & $96 \%$ & $94 \%$ & \\
\hline
\end{tabular}

Berdasarkan Tabel 2, diketahui bahwa guru memiliki kemampuan yang baik dalam mengelola kegiatan pembelajaran yang mengintegrasikan media KIT Listrik dan PhET dalam pembelajaran kooperatif tipe STAD. Slavin (2005:151) menyatakan bahwa ada empat tahapan yang dilakukan dalam kegiatan pembelajaran kooperatif tipe STAD, yaitu a) penyampaian tujuan pembelajaran dan materi pelajaran, b) siswa bekerja dan belajar dalam tim masing-masing, c) evaluasi, dan d) pemberian penghargaan. Dalam kegiatan pembelajaran, guru maupun siswa berperan secara aktif. Saat siswa sedang melakukan kegiatan percobaan dalam kelompok kecil, guru secara aktif memberikan arahan dan bimbingan sehingga kegiatan pembelajaran berlangsung dengan lancar.

Dalam penelitian ini kegiatan pembelajaran juga disesuaikan dengan Permendikbud No 81a Tahun 2013, yaitu menerapkan pendekatan tematik. Penerapan pendekatan tematik dilakukan dengan menghubungkan konsep yang terdapat pada mata pelajaran IPA, Bahasa Indonesia, dan Seni Budaya dan Prakarya melalui tema Bermain Dengan BendaBenda Sekitar dan subtema Energi Listrik di Sekitar Kita. Model pembelajaran tematik ini sesuai untuk digunakan pada siswa SD baik kelas awal (kelas I, II, dan III) maupun kelas lanjut (kelas IV, V, dan VI). Penelitian yang dilakukan oleh Liu dan Wang (2010) menunjukkan bahwa pembelajaran tematik berpengaruh positif terhadap siswa kelas V SD, yaitu dapat mengembangkan konsep-konsep materi yang saling berhubungan dan tepat digunakan untuk siswa yang memiliki kemampuan yang beraneka ragam.

Aktivitas Siswa dalam Kegiatan Pembelajaran

Aktivitas siswa yang diamati adalah membaca, berdiskusi, mencatat/menulis, mendengarkan, melakukan pengamatan, melakukan percobaan, menggambar, berpendapat, dan bertanya. Di bawah ini ditampilkan hasil pengamatan aktivitas siswa yang dilakukan oleh dua pengamat.

Tabel 3. Hasil Pengamatan Aktivitas Siswa

\begin{tabular}{|c|c|c|c|c|c|c|}
\hline \multirow{2}{*}{ No } & \multirow{2}{*}{ Aktivitas Siswa } & \multicolumn{4}{|c|}{ RPP ke- } & \multirow{2}{*}{$\begin{array}{r}\text { Rata- } \\
\text { rata }\end{array}$} \\
\hline & & 1 & 2 & 3 & 4 & \\
\hline 1 & Membaca & $11 \%$ & $7 \%$ & $11 \%$ & $7 \%$ & $9.0 \%$ \\
\hline 2 & Berdiskusi & $13 \%$ & $8 \%$ & $7 \%$ & $10 \%$ & $9.6 \%$ \\
\hline 3 & Mencatat $/$ menulis & $21 \%$ & $19 \%$ & $21 \%$ & $23 \%$ & $21.1 \%$ \\
\hline 4 & Mendengarkan & $6 \%$ & $6 \%$ & $6 \%$ & $4 \%$ & $5.6 \%$ \\
\hline 5 & $\begin{array}{l}\text { Melakukan } \\
\text { pengamatan }\end{array}$ & $6 \%$ & $8 \%$ & $7 \%$ & $4 \%$ & $6.1 \%$ \\
\hline 6 & $\begin{array}{l}\text { Melakukan } \\
\text { percobaan }\end{array}$ & $18 \%$ & $23 \%$ & $25 \%$ & $27 \%$ & $23.2 \%$ \\
\hline 7 & Menggambar & $10 \%$ & $11 \%$ & $10 \%$ & $10 \%$ & $10.4 \%$ \\
\hline 8 & Berpendapat & $7 \%$ & $9 \%$ & $5 \%$ & $8 \%$ & $7.3 \%$ \\
\hline 9 & $\begin{array}{l}\text { Bertanya kepada } \\
\text { guru }\end{array}$ & $7 \%$ & $8 \%$ & $9 \%$ & $7 \%$ & $7.7 \%$ \\
\hline Relic & litas & & $96 \%$ & $96 \%$ & $94 \%$ & $96 \%$ \\
\hline
\end{tabular}


Berdasarkan analisis terhadap hasil pengamatan aktivitas siswa pada Tabel 3, diketahui bahwa terdapat kecenderungan peningkatan frekuensi aktivitas siswa khususnya dalam hal melakukan kegiatan percobaan, menulis, dan menggambar. Ada beberapa aktivitas yang dominan dilakukan dalam kegiatan pembelajaran, antara lain melakukan percobaan, mencatat atau menulis, menggambar, berdiskusi dan membaca.

Berdasarkan data di atas, diketahui bahwa aktivitas siswa dalam kegiatan pembelajaran tidak hanya didominasi oleh kegiatan mendengarkan dan menulis saja, namun siswa juga berperan aktif dalam membangun pengetahuan bagi dirinya. Hal ini sesuai dengan teori mengenai konstruktivis dari Vygotsky (dalam Nur dan Wikandari, 2000:4) yang menyatakan bahwa saat siswa dihadapkan pada proses berfikir dengan teman sebaya mereka, maka terdapat dua keuntungan yang dapat diperoleh, yaitu hasil belajar terbuka untuk seluruh siswa dan membuat proses berpikir siswa lain terbuka untuk seluruh siswa.

Kegiatan percobaan dilakukan untuk melatih siswa dalam mempelajari materi mengenai rangkaian listrik menggunakan media KIT listrik dan media PhET. Penggunaan dua media ini dimaksudkan untuk melatih siswa dalam belajar menggunakan benda-benda konkret (KIT listrik) maupun benda-benda yang bersifat visual (PhET). Sesuai dengan teori yang dikemukakan oleh Piaget mengenai tahapan perkembangan belajar anak, siswa kelas $\mathrm{V}$ sekolah dasar tergolong pada tahap operasional konkret dan ada yang masuk dalam tahap operasional formal. Pada tahap operasional konkret, anak-anak dapat membentuk konsep, menjalin hubungan antarbagian maupun objek sebagai suatu kesatuan (bagian yang utuh), dan memecahkan masalah, tetapi hanya melibatkan objek dan situasi yang telah dikenal.

Penerapan teori Piaget tersebut dalam kegiatan pembelajaran tampak saat siswa diberi kesempatan untuk melakukan kegiatan percobaan menggunakan media KIT listrik. Siswa menggunakan benda-benda konkret berupa baterai, lampu, kabel, dan sakelar untuk dirangkai menjadi berbagai rangkaian listrik. Dalam teori Dale's Cone of Experiences (dalam Munadi, 2012:19) dinyatakan bahwa tingkat pemerolehan informasi seseorang yang melakukan kegiatan simulasi atau percobaan secara nyata mencapai $90 \%$.

Setelah siswa melakukan percobaan menggunakan media KIT, siswa diberi kesempatan untuk melakukan percobaan menggunakan media PhET. Media PhET ini tidak hanya didemontrasikan oleh guru, tetapi siswa diberi kesempatan untuk belajar secara langsung melalui konsep laboratorium virtual. Dengan memanfaatkan media PhET dalam kegiatan percobaan, siswa dapat mempelajari konsep-konsep yang tidak dapat dilihat secara langsung ketika siswa melakukan eksperimen menggunakan media KIT listrik. Salah satu konsep yang dapat dipelajari menggunakan media PhET ini adalah visualisasi dari aliran arus listrik dalam rangkaian berseta pengaruhnya terhadap nyala lampu.

Ketika siswa belajar menggunakan KIT listrik, siswa dapat mengamati dampak yang ditimbulkan ketika suatu rangkaian listrik disusun secara tertutup, yaitu lampu dapat menyala. Namun siswa belum dapat mengamati proses suatu lampu dapat menyala ketika dirangkai secara tertutup, yaitu proses aliran arus listrik dalam rangkaian tersebut. Keterbatasan dari media KIT listrik ini dapat diatasi dengan memanfaatkan media PhET. Penelitian terdahulu yang menunjukkan bahwa media PhET efektif dalam meningkatkan kemampuan siswa disampaikan oleh McKagan, dkk (2008:415) yang menyatakan bahwa setelah siswa melakukan simulasi menggunakan media PhET, siswa mampu menjelaskan perubahan energi yang terjadi pada dari suatu elektron menjadi energi cahaya.

\section{HASIL BELAJAR SISWA}

Hasil belajar siswa dalam penelitian ini terbagi dalam 3 aspek, yaitu sikap, pengetahuan, dan keterampilan. Di bawah ini ditampilkan tabel hasil penilaian terhadap aspek sikap siswa.

Tabel 4. Rekapitulasi Penilaian Aspek Sikap Siswa

\begin{tabular}{|c|c|c|c|c|c|c|}
\hline \multirow[t]{2}{*}{ No } & \multirow[t]{2}{*}{$\begin{array}{l}\text { Aspek yang } \\
\text { Dinilai }\end{array}$} & \multicolumn{4}{|c|}{$\begin{array}{c}\text { Jumlah Siswa } \\
\text { dengan Nilai } \\
\text { Modus }\end{array}$} & \multirow[t]{2}{*}{$\begin{array}{l}\text { Nilai } \\
\text { Rata- } \\
\text { rata }\end{array}$} \\
\hline & & 1 & 2 & 3 & 4 & \\
\hline 1 & $\begin{array}{l}\text { Perilaku } \\
\text { bersyukur }\end{array}$ & - & - & 10 & 27 & 3,7 \\
\hline 2 & Jujur & - & - & 15 & 22 & 3,6 \\
\hline 3 & Disiplin & - & - & 24 & 13 & 3,4 \\
\hline 4 & Teliti & - & - & 19 & 18 & 3,5 \\
\hline 5 & Tanggung jawab & - & - & 10 & 27 & 3,7 \\
\hline 6 & Kerja sama & - & - & 13 & 24 & 3,6 \\
\hline 7 & Percaya diri & - & - & 24 & 13 & 3,4 \\
\hline
\end{tabular}

Dengan berpedoman pada Permendikbud Nomor 104 Tahun 2014 yang menjelaskan bahwa 
peserta didik dikatakan tuntas pada apek sikap jika memiliki nilai minimal B, maka siswa yang dinyatakan tuntas pada kompetensi sikap sebanyak 37 anak. Selain menggunakan instrumen lembar pengamatan, siswa juga diberi kesempatan untuk menilai dirinya sendiri. Di bawah ini disajikan tabel mengenai hasil penilaian diri siswa.

Tabel 5. Rekapitulasi Penilaian Diri Siswa

\begin{tabular}{|c|c|c|c|c|c|c|}
\hline \multirow[t]{2}{*}{ No } & \multirow[t]{2}{*}{$\begin{array}{c}\text { Aspek yang } \\
\text { Dinilai }\end{array}$} & \multicolumn{4}{|c|}{$\begin{array}{c}\text { Jumlah Siswa } \\
\text { dengan Nilai } \\
\text { Modus }\end{array}$} & \multirow[t]{2}{*}{$\begin{array}{l}\text { Mo } \\
\text { dus }\end{array}$} \\
\hline & & 1 & 2 & 3 & 4 & \\
\hline 1 & $\begin{array}{l}\text { Perilaku } \\
\text { bersyukur }\end{array}$ & - & - & 9 & 28 & 4 \\
\hline 2 & Jujur & - & - & 6 & 31 & 4 \\
\hline 3 & Disiplin & - & - & 18 & 19 & 4 \\
\hline 4 & Teliti & - & - & 10 & 27 & 4 \\
\hline 5 & $\begin{array}{l}\text { Tanggung } \\
\text { jawab }\end{array}$ & - & - & 9 & 28 & 4 \\
\hline 6 & Kerja sama & - & - & 12 & 25 & 4 \\
\hline 7 & Percaya diri & - & - & 29 & 8 & 3 \\
\hline
\end{tabular}

Dalam Permendikbud Nomor 104 Tahun 2014 dijelaskan bahwa penilaian diri digunakan untuk memberikan penguatan (reinforcement) terhadap kemajuan proses belajar peserta didik. Penilaian diri berperan penting dalam melatih siswa memahami konsep belajar mandiri (autonomous learning). Berdasarkan Tabel 5 di atas, diketahui bahwa seluruh siswa memiliki konsep diri yang positif. Hal ini sesuai dengan hasil penelitian terdahulu yang telah dilakukan oleh Tran (2013) dan Wyk (2012). Tran (2013:9) menyatakan bahwa dampak dari pembelajaran STAD dapat meningkatkan prestasi siwa dan memperluas sikap positif siswa dalam belajar. Sementara itu Wyk (2012:269) menyatakan bahwa penggunaan model pembelajaran kooperatif tipe STAD yang dipadukan dengan pembelajaran langsung dapat meningkatkan prestasi maupun mengembangkan sikap positif siswa dalam belajar.

Hasil belajar siswa pada aspek pengetahuan diukur menggunakan Instrumen Lembar Penilaian Pengetahuan (Instrumen 4b). Dalam permendikbud Nomor 104 Tahun 2014 dijelaskan bahwa peserta didik dinyatakan tuntas belajar jika mampu memperoleh indikator nilai $\geq 2,67$ dari hasil tes pengetahuan yang diberikan. Tingkat ketuntasan baik individual maupun klasikal juga meningkat setelah dilakukan kegiatan pembelajaran dengan memanfaatkan media PhET dan KIT listrik. Di bawah ini ditampilkan hasil belajar siswa pada aspek pengetahuan untuk tiap indikator.
Tabel 6. Rekapitulasi Ketuntasan Siswa Aspek Pengetahuan IPA Tiap Indikator

\begin{tabular}{|c|c|c|c|}
\hline \multirow{2}{*}{ No } & \multirow{2}{*}{ Indikator } & \multicolumn{2}{|c|}{$\begin{array}{l}\text { Nilai rata- } \\
\text { rata }\end{array}$} \\
\hline & & $\mathbf{O}_{1}$ & $\mathbf{O}_{2}$ \\
\hline 1 & Menyebutkan contoh energi listrik & 1.41 & 3.35 \\
\hline 2 & $\begin{array}{l}\text { Menjelaskan perubahan energi } \\
\text { listrik }\end{array}$ & 1.73 & 3.46 \\
\hline 3 & Menjelaskan kegunaan sakelar & 1.51 & 2.70 \\
\hline 4 & $\begin{array}{l}\text { Menjelaskan pengertian rangkaian } \\
\text { listrik terbuka }\end{array}$ & 0.97 & 2.70 \\
\hline 5 & $\begin{array}{l}\text { Mengidentifikasi penggunaan } \\
\text { rangkaian listrik terbuka }\end{array}$ & 1.62 & 3.14 \\
\hline 6 & $\begin{array}{l}\text { Menjelaskan rangkaian listrik } \\
\text { tertutup }\end{array}$ & 1.41 & 2.81 \\
\hline 7 & $\begin{array}{l}\text { Mengidentifikasi penggunaan } \\
\text { rangkaian listrik tertutup }\end{array}$ & 1.51 & 2.81 \\
\hline 8 & $\begin{array}{l}\text { Menerapkan desain rangkaian } \\
\text { listrik tertutup }\end{array}$ & 0.00 & 3.57 \\
\hline 9 & $\begin{array}{l}\text { Menjelaskan pengertian rangkaian } \\
\text { listrik seri }\end{array}$ & 0.65 & 3.89 \\
\hline 10 & $\begin{array}{l}\text { Mengidentifikasi rangkaian listrik } \\
\text { seri }\end{array}$ & 1.62 & 3.68 \\
\hline 11 & $\begin{array}{l}\text { Menyebutkan keuntungan } \\
\text { rangkaian listrik seri }\end{array}$ & 1.84 & 3.46 \\
\hline 12 & $\begin{array}{l}\text { Menyebutkan kerugian rangkaian } \\
\text { listrik seri }\end{array}$ & 0.32 & 3.57 \\
\hline 13 & $\begin{array}{l}\text { Mengidentifikasi penggunaan } \\
\text { rangkaian listrik seri dalam } \\
\text { kehidupan sehari-hari }\end{array}$ & 1.30 & 3.68 \\
\hline 14 & $\begin{array}{l}\text { Menerapkan rangkaian listrik seri } \\
\text { untuk mengatasi permasalahan } \\
\text { sehari-hari }\end{array}$ & 0.00 & 2.81 \\
\hline 15 & $\begin{array}{l}\text { Menjelaskan pengertian rangkaian } \\
\text { listrik pararel }\end{array}$ & 1.08 & 3.89 \\
\hline 16 & $\begin{array}{l}\text { Mengidentifikasi rangkaian listrik } \\
\text { pararel }\end{array}$ & 1.41 & 3.89 \\
\hline 17 & $\begin{array}{l}\text { Menyebutkan keuntungan } \\
\text { rangkaian listrik pararel }\end{array}$ & 0.97 & 3.68 \\
\hline 18 & $\begin{array}{l}\text { Menyebutkan kerugian rangkaian } \\
\text { listrik pararel }\end{array}$ & 1.51 & 3.78 \\
\hline 19 & $\begin{array}{l}\text { Mengidentifikasi penggunaan } \\
\text { rangkaian listrik pararel dalam } \\
\text { kehidupan sehari-hari }\end{array}$ & 0.97 & 3.46 \\
\hline 20 & $\begin{array}{l}\text { Menerapkan rangkaian listrik } \\
\text { pararel untuk mengatasi } \\
\text { permasalahan sehari-hari }\end{array}$ & 0.00 & 2.81 \\
\hline 21 & $\begin{array}{l}\text { Menjelaskan pengertian rangkaian } \\
\text { listrik campuran }\end{array}$ & 1.41 & 3.89 \\
\hline 22 & $\begin{array}{l}\text { Mengidentifikasi bentuk rangkaian } \\
\text { listrik campuran }\end{array}$ & 1.51 & 3.68 \\
\hline 23 & $\begin{array}{l}\text { Mengidentifikasi fungsi bagian- } \\
\text { bagian rangkaian listrik campuran }\end{array}$ & 0.97 & 3.57 \\
\hline 24 & $\begin{array}{l}\text { Mengidentifikasi contoh } \\
\text { penggunaan rangkaian listrik } \\
\text { campuran dalam kehidupan sehari- } \\
\text { hari }\end{array}$ & 0.65 & 3.68 \\
\hline 25 & $\begin{array}{l}\text { Menerapkan rangkaian listrik } \\
\text { campuran untuk mengatasi } \\
\text { permasalahan sehari-hari }\end{array}$ & 0.00 & 3.03 \\
\hline
\end{tabular}


Tabel 7. Rekapitulasi Nilai Aspek Pengetahuan IPA Siswa

\begin{tabular}{|c|c|c|c|c|c|c|c|}
\hline \multirow{3}{*}{ No } & \multirow{3}{*}{$\begin{array}{c}\text { Mata } \\
\text { Pelajar } \\
\text { an }\end{array}$} & \multicolumn{2}{|c|}{$\begin{array}{l}\text { Nilai Rata- } \\
\text { rata }\end{array}$} & \multicolumn{4}{|c|}{ Ketuntasan } \\
\hline & & \multirow{2}{*}{$\mathbf{O}_{1}$} & \multirow{2}{*}{$\mathbf{O}_{2}$} & \multicolumn{2}{|c|}{$\begin{array}{c}\text { Individ } \\
\text { ual }\end{array}$} & \multicolumn{2}{|c|}{$\begin{array}{c}\% \\
\text { Klasikal }\end{array}$} \\
\hline & & & & $\mathbf{O}_{1}$ & $\mathrm{O}_{2}$ & $\mathrm{O}_{1}$ & $\mathrm{O}_{2}$ \\
\hline 1 & IPA & 0,94 & 3,35 & 0 & 37 & 0 & 100 \\
\hline 2 & $\begin{array}{l}\text { Bahasa } \\
\text { Indones } \\
\text { ia }\end{array}$ & 1,66 & 3,65 & 5 & 37 & 14 & 100 \\
\hline 3 & $\mathrm{SBdP}$ & 1,27 & 3,64 & 5 & 37 & 14 & 100 \\
\hline
\end{tabular}

Berdasarkan Tabel 7 diketahui terjadi peningkatan hasil belajar siswa pada aspek pengetahuan IPA yaitu dari 0,94 saat pretes menjadi 3,35 saat postes. Tingkat ketuntasan baik individual maupun klasikal juga meningkat setelah dilakukan kegiatan pembelajaran dengan memanfaatkan media PhET dan KIT listrik. Peningkatan hasil belajar siswa pada aspek pengetahuan juga terjadi pada mata pelajaran Bahasa Indonesia yaitu dari 1,66 saat pretes menjadi 3,65 saat postes dan mata pelakaran Seni Budaya dan Prakarya yaitu dari 1,27 saat pretes menjadi 3,64 saat postes.

Peningkatan hasil belajar siswa pada aspek pengetahuan juga terjadi pada mata pelajaran Bahasa Indonesia yaitu dari 1,66 saat pretes menjadi 3,65 saat postes dan mata pelakaran Seni Budaya dan Prakarya yaitu dari 1,27 saat pretes menjadi 3,64 saat postes.

Dalam Permendikbud Nomor 104 tahun 2014 dijelaskan bahwa ketuntasan minimal untuk semua kompetensi dasar pada kompetensi pengetahuan adalah 2,67. Berdasarkan Peraturan Menteri tersebut, maka dapat disimpulkan bahwa seluruh siswa telah mencapai ketuntasan minimal. Ketuntasan klasikal juga tercapai karena lebih dari $75 \%$ dari seluruh siswa telah tuntas secara individual. Ketuntasan baik secara individual maupun klasikal juga tampak pada mata pelajaran Bahasa Indonesia dan Seni Budaya dan Prakarya.

Hasil belajar siswa pada aspek pengetahuan setelah mengikuti kegiatan pembelajaran yang memadukan penggunaan media PhET dan KIT listrik melalui model pembelajaran kooperatif Tipe STAD meningkat jika dibandingkan nilai yang diperoleh saat pretes. Hal ini mengindikasikan adanya pengaruh positif dari penggunaan media $\mathrm{PhET}$, KIT listrik, dan model pembelajaran kooperatif Tipe STAD ketika digunakan secara kolaboratif dalam kegiatan pembelajaran terhadap pencapaian kompetensi yang perlu dikuasai siswa. Piaget (dalam Dimyati dan Mudjiono, 2010:14) menyatakan bahwa pengetahuan dibentuk oleh individu yang melakukan interaksi secara terusmenerus dengan lingkungan.

Melalui kegiatan pembelajaran dengan model kooperatif tipe STAD, siswa saling membantu dalam kegiatan belajar kelompok. Hal ini berpengaruh positif terhadap perkembangan kemampuan pengetahuan seluruh siswa dalam satu kelompok. Menurut Nur dan Wikandari (2000:4) dalam pembelajaran kooperatif, siswa dihadapkan pada proses berpikir teman sebaya mereka; metode ini tidak hanya membuat hasil belajar terbuka untuk seluruh siswa, tetapi juga membuat proses berpikir siswa lain terbuka untuk seluruh siswa. Saat kegiatan belajar dalam kelompok kecil berlangsung, siswa dari setiap kelompok yang masih belum memahami materi pelajaran, dibimbing oleh teman sekelompoknya untuk menguasai materi. Seluruh siswa aktif dalam kegiatan percobaan maupun diskusi. Penelitian yang dilakukan oleh Tran (2013:9) menyatakan bahwa penggunaan model pembelajaran kooperatif tipe STAD dapat meningkatkan interaksi antarsiswa dalam belajar, meningkatkan prestasi belajar, dan meningkatkan sikap positif dalam belajar.

Kegiatan percobaan yang dilakukan siswa baik menggunakan KIT listrik maupun PhET juga memiliki peran penting terhadap pencapaian target kompetensi pengetahuan yang harus dikuasai siswa. Siswa melakukan aktivitas percobaan baik menggunakan PhET sebagai laboratorium virtual maupun KIT listrik sebagai laboratorium nyata. Dengan memanfaatkan kedua media tersebut, siswa dapat mempelajari konsep susunan rangkaian listrik, fungsi tiap komponen yang terdapat dalam rangkaian listrik, maupun proses yang terjadi ketika suatu rangkaian listrik tersusun secara terbuka atau tertutup.

Berbagai aktivitas pengamatan dan percobaan dapat meningkatkan pemahaman siswa terhadap materi pelajaran. Dalam penelitian ini aktivitas siswa dalam melakukan kegiatan pengamatan mencapai 6\% dan aktivitas siswa dalam melakukan percobaan mencapai 23\%. Dale (dalam Munadi, 2012:19) menyatakan bahwa kegiatan percobaan memiliki kontribusi yang tinggi terhadap pemerolehan informasi ataupun daya ingat siswa yaitu sebesar $90 \%$. Semakin tinggi tingkat penguasaan siswa terhadap materi pelajaran, berdampak pada peningkatan prestasi siswa yang ditunjukkan melalui peningkatan nilai hasil belajar. Abraham dan Milar (2008:1965) menjelaskan 
bahwa melalui kegiatan praktikum, siswa dapat mengembangkan pemikiran mengenai hubungan antara hasil pengamatan dengan teori-teori atau ide yang mendasarinya. Penelitian yang dilakukan oleh Finkelstein dkk (2005) menunjukkan bahwa terdapat pengaruh positif ketika media PhET digunakan dalam kegiatan pembelajaran. Finkelstein dkk (2005:1) menyatakan bahwa setelah melakukan simulasi menggunakan PhET, siswa dapat memahami konsep dan menjelaskan proses yang terjadi dalam suatu rangkaian nyata.

Dalam permendikbud Nomor 104 Tahun 2014 dijelaskan bahwa peserta didik dinyatakan tuntas belajar dalam aspek keterampilan jika mampu memperoleh indikator nilai $\geq 2,67$. Di bawah ini ditampilkan hasil belajar siswa pada aspek keterampilan IPA untuk tiap indikator.

Tabel 8. Rekapitulasi Nilai Rata-rata Siswa Aspek Keterampilan IPA Tiap Indikator

\begin{tabular}{|c|c|c|c|}
\hline \multirow{2}{*}{ No } & \multirow{2}{*}{ Indikator } & \multicolumn{2}{|c|}{$\begin{array}{l}\text { Nilai rata- } \\
\text { rata }\end{array}$} \\
\hline & & $\mathbf{O}_{1}$ & $\mathrm{O}_{2}$ \\
\hline 1 & $\begin{array}{l}\text { Menyusun desain rangkaian listrik } \\
\text { terbuka }\end{array}$ & 2,35 & 3,74 \\
\hline 2 & $\begin{array}{l}\text { Menyusun rangkaian listrik } \\
\text { terbuka menggunakan media } \\
\text { PhET }\end{array}$ & 1,07 & 3,47 \\
\hline 3 & $\begin{array}{l}\text { Menuliskan hasil pengamatan } \\
\text { rangkaian listrik terbuka dalam } \\
\text { tabel }\end{array}$ & 2,24 & 3,70 \\
\hline 4 & $\begin{array}{l}\text { Menyusun rangkaian listrik } \\
\text { terbuka menggunakan media KIT } \\
\text { listrik }\end{array}$ & 1,01 & 3,26 \\
\hline 5 & $\begin{array}{l}\text { Menyusun hipotesis mengenai } \\
\text { rangkaian listrik tertutup }\end{array}$ & 1,43 & 3,34 \\
\hline 6 & $\begin{array}{l}\text { Menyususn desain rangkaian } \\
\text { listrik tertutup }\end{array}$ & 1,97 & 3,58 \\
\hline 7 & $\begin{array}{l}\text { Menyusun rangkaian listrik } \\
\text { tertutup menggunakan media } \\
\text { PhET }\end{array}$ & 1,00 & 3,46 \\
\hline 8 & $\begin{array}{l}\text { Menyusun rangkaian listrik } \\
\text { tertutup menggunakan media KIT } \\
\text { listrik }\end{array}$ & 1,00 & 3,23 \\
\hline 9 & $\begin{array}{l}\text { Menuliskan hasil pengamatan } \\
\text { rangkaian listrik tertutup dalam } \\
\text { tabel }\end{array}$ & 2,38 & 3,73 \\
\hline 10 & $\begin{array}{l}\text { Membuat simpulan mengenai ciri- } \\
\text { ciri rangkaian listrik tertutup }\end{array}$ & 1,84 & 3,24 \\
\hline 11 & $\begin{array}{l}\text { Menyusun desain rangkaian listrik } \\
\text { seri }\end{array}$ & 1,00 & 3,04 \\
\hline 12 & $\begin{array}{l}\text { Menyusun rangkaian listrik seri } \\
\text { menggunakan media PhET }\end{array}$ & 1,05 & 3,35 \\
\hline 13 & $\begin{array}{l}\text { Menuliskan hasil pengamatan } \\
\text { rangkaian listrik seri dalam tabel }\end{array}$ & 2,34 & 3,78 \\
\hline 14 & $\begin{array}{l}\text { Menyusun rangkaian listrik seri } \\
\text { menggunakan media KIT listrik }\end{array}$ & 1,00 & 3,76 \\
\hline 15 & $\begin{array}{l}\text { Membuat simpulan mengenai ciri- } \\
\text { ciri rangkaian listrik seri }\end{array}$ & 1,20 & 2,93 \\
\hline 16 & $\begin{array}{l}\text { Menyusun desain rangkaian listrik } \\
\text { paralel }\end{array}$ & 1,51 & 3,01 \\
\hline
\end{tabular}

17 Menyusun rangkaian listrik paralel menggunakan media PhET

$1,05 \quad 3,27$

18 Menyusun hipotesis mengenai rangkaian listrik paralel yang

diambil lampunya

19 Menyusun rangkaian listrik paralel menggunakan media KIT listrik

$2,10 \quad 3,65$

20 Menuliskan hasil pengamatan rangkaian listrik paralel dalam $\quad 1,00 \quad 3,03$ tabel

21 Membuat simpulan mengenai ciriciri rangkaian listrik paralel

$1,12 \quad 3,15$

22 Menyusun desain rangkaian listrik campuran

$1,64 \quad 3,16$

23 Menyusun rangkaian listrik campuran menggunakan media PhET

24 Menyusun rangkaian listrik campuran menggunakan media $\quad 1,00 \quad 3,01$ KIT listrik

25 Menuliskan hasil pengamatan rangkaian listrik campuran dalam $\quad 2,00 \quad 3,66$ tabel

$26 \begin{aligned} & \text { Membuat simpulan mengenai ciri- } \\ & \text { ciri rangkaian listrik campuran }\end{aligned} \quad 1,03 \quad 2,85$

Berdasarkan Tabel 8, diketahui terjadi peningkatan hasil belajar siswa pada aspek keterampilan IPA. Keterampilan siswa baik dalam hal menyususn rangkaian listrik, melakukan pengamatan, mengomunikasikan hasil pengamatan baik dalam bentuk tabel, dan membuat simpulan mengenai rangkaian listrik mengalami peningkatan selatah mengikuti kegiatan pembelajaran yang memanfaatkan media PhET dan KIT listrik. Pada tabel 9 berikut ditampilkan rekapitulasi nilai ratarata keterampilan siswa untuk pelajaran IPA, Bahasa Indonesia, dan Seni Budaya dan Prakarya.

Tabel 9. Rekapitulasi Nilai Keterampilan siswa

\begin{tabular}{|c|c|c|c|c|c|c|c|}
\hline \multirow{4}{*}{ No } & \multirow{4}{*}{$\begin{array}{c}\text { Mata } \\
\text { Pelajara } \\
\mathbf{n}\end{array}$} & \multicolumn{2}{|c|}{$\begin{array}{c}\text { Nilai Rata- } \\
\text { rata }\end{array}$} & \multicolumn{4}{|c|}{ Ketuntasan } \\
\hline & & \multirow{3}{*}{01} & \multirow{3}{*}{$\mathbf{O 2}$} & \multirow{2}{*}{\multicolumn{2}{|c|}{$\begin{array}{c}\text { Individ } \\
\text { ual }\end{array}$}} & \multirow{2}{*}{\multicolumn{2}{|c|}{$\begin{array}{c}\% \\
\text { Klasikal }\end{array}$}} \\
\hline & & & & & & & \\
\hline & & & & 01 & $\mathbf{O 2}$ & O1 & $\mathbf{O 2}$ \\
\hline 1 & IPA & 1,65 & 3,34 & 0 & 37 & 0 & 100 \\
\hline 2 & $\begin{array}{l}\text { Bahasa } \\
\text { Indonesia }\end{array}$ & 1,62 & 2,99 & 0 & 37 & 0 & 100 \\
\hline 3 & SBdP & 1,97 & 3,21 & 1 & 37 & 3 & 100 \\
\hline
\end{tabular}

Penggunaan model pembelajaran kooperatif tipe STAD mengakomodasi kebutuhan siswa untuk belajar dari berbagai sumber, khususnya pada tahap siswa bekerja dan belajar dalam kelompok kecil, seluruh siswa diberi kesempatan untuk saling membantu dalam mendesain dan menyusun rangkaian listrik. Kegiatan-kegiatan tersebut tampak pada aktivitas siswa seperti diskusi yang mencapai $9,6 \%$, melakukan percobaan yang 
mencapai 23,2\%, aktivitas membaca yang mencapai $9 \%$, berpendapat mencapai $7,3 \%$, dan aktivitas bertanya mencapai 7,7\%. Dampak dari kegiatan ini terlihat pada hasil belajar aspek keterampilan siswa yang teramati setelah mengikuti kegiatan pembelajaran. Berdasarkan Tabel 9 diketahui bahwa nilai rata-rata aspek keterampilan siswa pada pelajaran IPA untuk pertemuan pertama mencapai 3,77 .

Pada pertemuan pertama siswa diminta melakukan serangkaian kegiatan untuk mengetahui keterampilan proses maupun keterampilan psikomotor siswa dalam menyusun rangkaian listrik terbuka maupun rangkaian listrik tertutup. Keterampilan proses tampak saat siswa melakukan kegiatan pengamatan, pembuatan model atau desain rangkaian listrik, pengkomunikasian hasil pengamatan dalam bentuk tabel, dan membuat simpulan berdasarkan hasil percobaan. Hasil belajar siswa berkaitan dengan keterampilan psikomotor tampak saat siswa membuat rangkaian listrik terbuka dan rangkaian listrik tertutup baik menggunakan media PhET maupun media KIT listrik. Secara klasikal, siswa tidak menunjukkan kesulitan dalam menyusun rangkaian listrik menggunakan media PhET. Cara menggunakan software PhET untuk menyusun rangkaian listrik memiliki kemiripan dengan permainan game pada benda-benda elektronik saat ini seperti game pada telepon genggam, laptop, komputer, atau tab. Siswa hanya perlu merangkai icon kabel, baterai, lampu, dan sakelar dengan menggeser dan menyambungkan icon-icon tersebut sesuai dengan desain rangkaian listrik tertentu.

Keterampilan proses maupun keterampilan psikomotor siswa terus dilatihkan pada pertemuan kedua hingga keempat yang membahas tentang rangkaian listrik seri, paralel, dan campuran. Melalui kegiatan interaksi dengan teman sebaya yang ditunjukkan melalui kegiatan diskusi serta interaksi dengan lingkungan, siswa dapat meningkatkan kompetensi pengetahuan maupun keterampilannya. Menurut Winkel (dalam Riyanto, 2010:5) suatu aktivitas mental atau psikis yang berlangsung dalam interaksi aktif dengan lingkungan (kegiatan belajar) dapat menghasilkan perubahan dalam pengetahuan, pemahaman, keterampilan, dan nilai sikap.

Kegiatan bekerja dan belajar dalam kelompok kecil mengakomodasi kebutuhan belajar siswa untuk berinteraksi secara langsung baik dengan guru, teman sebaya, maupun dengan lingkungan sekitar (termasuk media PhET dan KIT listrik) dalam meningkatkan kompetensi keterampilan siswa. Dampak penggunaan model pembelajaran kooperatif dengan memanfaatkan media PhET dan KIT terhadap pencapaian ketuntasan belajar juga pernah disampaikan oleh Samsuri (2010). Dalam penelitian tersebut dijelaskan bahwa pembelajaran yang dilaksanakan menggunakan model kooperatif dan pengajaran langsung serta memanfaatkan media PhET dan KIT sederhana dapat menuntaskan hasil belajar produk, proses, dan psikomotor siswa baik secara individual maupun klasikal.

Dalam penelitian ini, diketahui bahwa ketuntasan belajar siswa tidak hanya tampak pada mata pelajaran IPA saja, melainkan juga tampak pada pelajaran Bahasa Indonesia dan Seni Budaya dan Prakarya. Penilaian terhadap aspek keterampilan untuk pelajaran Bahasa Indonesia dilakukan dengan menggunakan penilaian kinerja dan penilaian produk, yaitu meminta siswa membuat paragraf narasip yang menjelaskan mengenai rangkaian listrik terbuka, rangkaian listrik tertutup, rangkaian listrik seri, rangkaian listrik paralel, dan rangkaian listrik campuran. Berdasarkan Tabel 9 diketahui bahwa nilai rata-rata aspek keterampilan siswa pada pelajaran Bahasa Indonesia mencapai 2,99, sedangkan untuk pelajaran Seni Budaya dan Prakarya mencapai 3,21. Penilaian aspek keterampilan untuk pelajaran SBdP dilakukan dengan menggunakan penilaian penilaian kinerja dan penilaian produk, yaitu meminta siswa membuat gambar ilustrasi dari rangkaian listrik tertutup, rangkaian listrik seri, rangkaian listrik paralel, dan rangkaian listrik campuran.

Pelaksanaan Kuis STAD

Tabel 10. Rekapitulasi Skor Kuis STAD

\begin{tabular}{|c|c|c|c|c|c|c|}
\hline \multirow{2}{*}{$\begin{array}{l}\mathbf{N} \\
\mathbf{o}\end{array}$} & \multirow{2}{*}{$\begin{array}{l}\text { Nama } \\
\text { Kelompo } \\
\text { k }\end{array}$} & \multicolumn{4}{|c|}{$\begin{array}{l}\text { Rata-rata Skor Perbaikan } \\
\text { Anggota Tim Tiap } \\
\text { Pertemuan }\end{array}$} & \multirow{2}{*}{$\begin{array}{l}\text { Rata- } \\
\text { rata } \\
\text { skor } \\
\text { perba } \\
\text { ikan } \\
\text { Tim }\end{array}$} \\
\hline & & $\begin{array}{l}\text { PB } \\
\text { M } 1\end{array}$ & $\begin{array}{l}\text { PB } \\
\text { M } 2\end{array}$ & $\begin{array}{l}\text { PB } \\
\text { M } 3\end{array}$ & $\begin{array}{l}\text { PB } \\
\text { M } 4\end{array}$ & \\
\hline 1 & Kompak & 30 & 20 & 25 & 20 & 23,8 \\
\hline 2 & Dangdut & 30 & 15 & 23 & 25 & 23,1 \\
\hline 3 & Semangat & 30 & 28 & 22 & 16 & 24,0 \\
\hline 4 & Panasonic & 30 & 18 & 28 & 25 & 25,0 \\
\hline 5 & SBHC & 30 & 14 & 22 & 18 & 21,0 \\
\hline 6 & Doraemon & 30 & 30 & 20 & 20 & 25,0 \\
\hline 7 & Cheytoc & 30 & 26 & 20 & 14 & 22,5 \\
\hline 8 & $\begin{array}{l}\text { Tuperwar } \\
\mathrm{e}\end{array}$ & 22 & 18 & 16 & 22 & 21,5 \\
\hline
\end{tabular}


Berdasarkan Tabel 10, diketahui terdapat dua kelompok yang mampu meraih predikat sebagai tim super. Predikat tim super diberikan pada kelompok yang mampu memperoleh nilai perbaikan rata-rata minimal 25 . Pencapaian prestasi oleh beberapa siswa ini bisa dimanfaatkan guru untuk memotivasi siswa lain yang masih meraih predikat sebagai kelompok baik maupun kelompok hebat agar terus belajar dan meningkatkan prestasi sehingga mampu meraih predikat sebagai kelompok super.

Pemberian penghargaan-penghargaan baik sebagai tim baik, tim hebat, maupun tim super dimaksudkan untuk memotivasi siswa dalam meningkatkan prestasi dan kontribusinya terhadap keberhasilan individu maupun kelompok. Hal ini terlihat pada perubahan sikap siswa dalam mengikuti kegiatan pembelajaran dan upaya saling membantu anggota kelompok untuk memahami materi yang dipelajari. Siswa menunjukkan kepedulian terhadap keberhasilan belajar temannya dalam kegiatan belajar dalam kelompok. Salah satu peran guru dalam memotivasi siswa terlihat saat menyampaikan informasi pada siswa bahwa setiap individu memiliki peran penting terhadap prestasi yang dicapai kelompok. Nilai skor perbaikan tiap individu dalam suatu kelompok berpengaruh positif pada pencapaian prestasi kelompok. Hal ini dapat mendorong siswa untuk saling membantu dalam memahami materi yang diajarkan karena semakin tinggi perolehan skor perbaikan individu maka prestasi yang dicapai oleh kelompok juga akan membaik. Slavin (dalam Sharan, 2009:7) menyatakan bahwa dari 22 penelitian tentang STAD di kelas III hingga kelas XII diperoleh hasil bahwa 17 di antaranya menunjukkan hasil yang signifikan terhadap pencapaian yang lebih baik dibandingkan saat siswa belajar menggunakan model pengajaran tradisional.

\section{Respon Siswa}

Berdasarkan hasil pengisian angket respon siswa terhadap pelaksanaan kegiatan pembelajaran, dapat diketahui bahwa seluruh siswa merasa senang dalam mengikuti kegiatan pembelajaran dengan memanfaatkan media KIT listrik dan PhET. Ada berbagai alasan yang menyebabkan siswa merasa senang. Alasan yang dominan adalah a) siswa merasa mendapat tambahan ilmu pengetahuan; b) banyak kegiatan praktik sehingga mengetahui alatalat percobaan IPA; c) cara guru menjelaskan materi dirasa jelas oleh siswa; dan d) dapat belajar mandiri dan memperoleh kesempatan berbicara, berpendapat atau bertanya. Garner dkk (dalam Nur, 2001:3) menyatakan bahwa siswa yang termotivasi untuk belajar sesuatu akan menggunakan proses kognitif yang lebih tinggi dalam mempelajari suatu materi, sehingga siswa dapat menyerap dan mengendapkan materi dengan lebih baik.

Dalam kegiatan pembelajaran guru membagi siswa dalam delapan kelompok. Setiap kelompok dimotivasi untuk saling membantu dalam kegiatan pembelajaran. Hal ini dapat meningkatkan kemampuan siswa dalam bekerja sama, meningkatkan rasa saling tolong menolong, serta meningkatkan sikap-sikap positif siswa. Berdasarkan hasil pengamatan dari observer melalui instrument pengamatan sikap, diketahui bahwa rata-rata skor hasil belajar siswa yang menunjukkan sikap positif antara lain a) perilaku bersyukur mencapai skor 3,7 ; b) perilaku jujur mencapai skor 3,57 ; c) perilaku disiplin mencapai skor 3,25 ; d) perilaku teliti mencapai skor 3,38; e) perilaku tanggung jawab mencapai skor 3,68 , dan f) kerja sama siswa mencapai skor 3,54. Selain bermanfaat positif bagi perkembangan aspek sikap, kerja kelompok juga dapat mempermudah siswa untuk memperoleh ilmu pengetahuan dari berbagai sumber, baik guru, teman satu kelompok, maupun teman dari kelompok lain. Guru juga memberi kesempatan bagi siswa untuk belajar melalui media $\mathrm{PhET}$ yang berguna dalam menyimulasikan rangkaian listrik menggunakan komputer.

Kendala dalam pembelajaran

Secara umum kendala yang muncul dalam kegiatan pembelajaran dapat dikategorikan dalam tiga hal, yaitu kendala yang berkaitan dengan pengelolaan kelas, pengelolaan waktu, dan kendala yang berkaitan dengan sarana pembelajaran. Permasalahan mengenai pengelolaan kelas antara lain siswa yang belum bisa mengatur giliran dalam menggunakan peralatan percobaan karena ingin lebih dulu menggunakan alat-alat. Solusi untuk mengatasi permasalahan ini adalah mengarahkan siswa untuk saling menghargai dan mengajarkan untuk bergiliran dalam menggunakan fasilitas yang ada.

Permasalahan lain adalah alokasi waktu pembelajaran yang perlu ditambah. Dalam pembelajaran tematik yang dilaksanakan pada penelitian ini, siswa mengkaji suatu materi dari sudut pandang IPA, Bahasa Indonesia, dan Seni Budaya dan Prakarya (SBdP). Berkaitan dengan 
keterbatasan jumlah sarana yang ada, siswa terpaksa bergantian dalam menggunakan peralatan percobaan. Maksud penambahan alokasi waktu pembelajaran adalah agar tiap siswa bisa berekplorasi lebih banyak dalam menggunakan media PhET dan KIT listrik. Permasalahan mengenai jumlah komputer yang belum mencukupi dapat diatasi dengan mengatur siswa untuk belajar secara berkelompok dan menggunakannya dalam kelompok kecil. Upaya lain yang dilakukan guru adalah memberi kesempatan pada tiap siswa untuk berlatih menggunakan komputer secara individual saat jam istirahat.

\section{PENUTUP}

Simpulan

1. Produk penelitian yang berhasil dikembangkan dalam penelitian ini adalah silabus, RPP, LKS, Lembar Penilaian, dan Modul Bahan Ajar Siswa.

2. Berdasarkan penilaian dari 2 pakar dan seorang praktisi pendidikan diketahui bahwa perangkat yang dikembangkan tergolong layak untuk digunakan dalam kegiatan pembelajaran.

3. Perangkat pembelajaran dapat diimplementasikan dengan baik. Hal ini didasarkan pada hasil pengamatan kepraktisan perangkat RPP oleh 2 observer yang menunjukkan nilai rata-rata dari seluruh aspek kegiatan pembelajaran mencapai skor 3,76 dengan reliabilitas di atas $93 \%$.

4. Ketika perangkat pembelajaran ini diimplementasikan menunjukkan hasil yang efektif dan baik. Hal ini didasarkan pada uraian sebagai beriku.

a. Siswa berperan aktif dalam kegiatan pembelajaran. Aktivitas siswa selama mengikuti kegiatan pembejaran yang menggunakan PhET dan KIT listrik dalam pembelajaran kooperatif tipe STAD didominasi oleh kegiatan melakukan percobaan, mencatat atau menulis baik mengenai hasil percobaan maupun mengerjakan tugas, dan membuat gambar ilustrasi.

b. Terdapat peningkatan hasil belajar siswa baik dalam aspek pengetahuan, dan keterampilan setelah digunakan media $\mathrm{PhET}$ dan KIT listrik dalam kegiatan pembelajaran dengan model STAD.

c. Respon siswa cukup positif dalam mengikuti kegiatan pembelajaran menggunakan media PhET dan KIT listrik yang dipadukan dengan model pembelajaran kooperatif tipe STAD.

d. Kendala-kendala yang dihadapi peneliti selama proses pembelajaran berkaitan dengan kesiapan sarana dan prasarana belajar, pengelolaan waktu, serta pengawasan terhadap siswa dalam mengikuti kegiatan pembelajaran

Saran

1. Perangkat pembelajaran yang mengintegrasikan media KIT Listrik dan PhET ini dapat dijadikan salah satu alternatif untuk diimplementasikan di sekolah.

2. Apabila ada ketersediaan sarana dan waktu maka dimungkinkan untuk menggunakan media PhET dan KIT sekaligus dalam suatu kegiatan pembelajaran. Namun apabila belum ada ketersediaan sarana maka dapat diantisipasi dengan melakukan kegiatan pembelajaran menggunakan media PhET.

3. Media PhET hendaknya dapat digunakan pada berbagai topik pembelajaran yang lain karena media PhET ini tidak hanya berisi tentang simulasi penyusunan rangkaian listrik saja, namun berbagai percobaan juga telah dikembangkan melalui software PhET.

4. Penggunaan instrumen penilaian diri untuk menilai sikap siswa kelas V SD memerlukan instrumen pendukung seperti lembar pengamatan sikap atau penilaian teman sejawat agar diperoleh hasil yang lebih akurat.

5. Bahan Ajar Siswa dan LKS sebaiknya disajikan dalam satu modul untuk memudahkan siswa dalam mempelajari materi.

\section{DAFTAR PUSTAKA}

Borich, Gary D. (1994). Observation for Efective Teaching. New York: Macmillan Publishing Company.

Dimyati dan Mudjiono. (2010). Belajar dan Pembelajarannya. Jakarta: Rineka Cipta.

Depdiknas. (2008). Peraturan Menteri Pendidikan Nasional. Jakarta: Dirjen Manajemen Pendidikan Dasar dan Menengah Departemen Pendidikan Nasional.

Finkelstein, N.D. dkk. (2005). "When Learning about the real world is better done virtually: A study of subtituting computer simulations for laboratory equipment". The American Physical Society. Colorado. USA

Johnson, David W., Roger T. Johnson, dan Edythe Johnson Holubec. (2012). Colaborative 
Learning: Strategi Pembelajaran untuk Sukses Bersama. Bandung: Nusa Media.

Kemdikbud. (2013). Peraturan Menteri Pendidikan dan Kebudayaan Tahun 2013. Jakarta.

Kemdikbud. (2014). Peraturan Menteri Pendidikan dan Kebudayaan Tahun 2014. Jakarta.

Khaeruddin dan Eko Hadi Sujiono. (2005). Pembelajaran Sains: Berdasarkan Kurikulum Berbasis Kompetensi. Makasar: State University of Makassar Press.

Liu, M.C dan Wang, J.Y. (2010). "Investigating Knowledge Integration in Web-based Thematic Learning Using Concept Mapping Assessment". Educational Technology \& Society, 13 (2).

McKagan, S.B. dkk. (2008). "Developing and Researching PhET Simulations for Teaching Quantum Mechanics". American Association of physics Teacher. Edisi April/Mei 2008.

Munadi, Yudhi. (2008). Media pembelajaran; Sebuah pendekatan Baru. Jakarta: Gaung Persada Press.

Nasution. (2010). Berbagai Pendekatan dalam Proses Belajar \& Mengajar. Jakarta: PT Bumi aksara.

Nur, Mohamad. (2001). Pemotivasian Siswa untuk Belajar. Surabaya: Universitas Negeri Surabaya.

Nur, Mohamad dan Wikandari, P. R. (2000). Pengajaran Berpusat Kepada Siswa dan Pendekatan Konstruktivis dalam Pengajaran. Surabaya: PSMS Unesa.

Riyanto, Yatim. (2010). Paradigma Baru pembelajaran. Surabaya: Kencana Prenada Media Group.

Saidah. (2013). Pengembangan Perangkat Pembelajaran Learning Cycle 5E berbasis KIT Sederhana dan PhET untuk Mereduksi Miskonsepsi Listrik Arus Searah (Tesis magister pendidikan tidak dipublikasikan). Universitas Negeri Surabaya.

Samsuri. (2010). Pengembangan Perangkat Pembelajaran Berbasis Media Simulasi PhET dan KIT Sederhana pada Pembelajaran Fisika SMA Pokok Bahasan Listrik Dinamis (Tesis magister pendidikan tidak dipublikasikan). Universitas Negeri Surabaya.

Sharan, Sholomo. (2009). Handbook of Cooperative Learning: Inovasi Pengajaran dan pembelajaran untuk Memacu Keberhasilan Siswa di Kelas. Yogyakarta: Imperium.
Slavin, Robert E. (2005). Cooperative Learning; Teori, Riset dan Praktik. Bandung: Nusa Media.

Sudjana, Nana dan Ahmad Rivai. (2005). Media Pengajaran. Bandung: Sinar Baru Algensindo.

Thiagarajan, S., Dorothy S. Semmel, dan Melvyn I. Semmel. (1974). Instructional Development for Training Teachers of Exceptional Children, a Sourcebook. Bloomingtoon: Center for Innovation on the Teaching the Handicapped. Indiana University.

Tran, Van Dat. (2013). "Effects of Student Teams Achievement Division (STAD) on Academic Achievement, and Attitudes of Grade 9th Secondary School Students towards Mathematics". International Journal of Sciences. Volume 2, April 2013.

Wyk, Micheal M Van. (2012). "The Effects of the STAD-Cooperative Learning Method on Student Achievement, Attitude and Motivation in Economics Education". Journal of Social Science edisi 33(2): 261-270 (2012).

www.phet.colorado.edu/in/about diakses tanggal 8 Januari 2014 pukul 11.34. 